\title{
The promised land of milk and honey? From EU citizens to third- country nationals after Brexit
}

Eglè Dagilyte்

\begin{abstract}
This chapter connects scholarly conversations to date (August 2019) on current and future EU and UK immigration rules and on EU citizenship as a status that entails a bundle of transnational rights. It concludes that in a case of no-deal Brexit, both UK nationals in EU-27 and EU citizens in the UK will face a future of complex European, national and international agreements, losing many EU citizenship rights they currently have. With the draft Withdrawal Agreement in limbo, it remains to be seen which rights - and to which extent will be incorporated into the transitionary legal arrangements across the EU Member States and the UK, as well as how far they will feature in the negotiations and the final text of the future EU-UK partnership agreement. One thing is certain: the concept of EU citizenship, with normative aspirations of a self-standing legal status that seemed to offer much hope in the 'golden age' era of Grzelczyk, Baumbast, Martínez Sala, Rottmann or Ruiz Zambrano, has been abandoned. It cannot be extended by the concept of acquired rights, continues to be tied to Member State nationality and woven into the strict black-letter-law wording of EU legislation.
\end{abstract}

\section{Keywords:}

EU citizenship, third-country nationals, Brexit, Settled Status, Withdrawal Agreement 


\section{Contents}

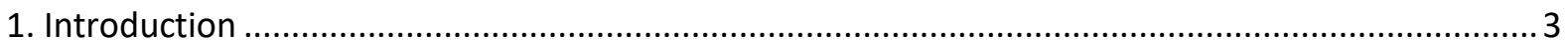

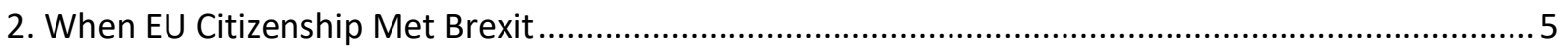

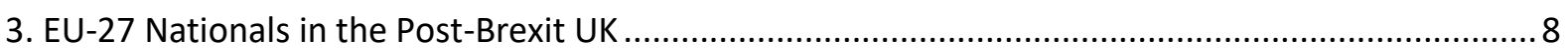

3.1. The practical arrangements of the UK Settlement Scheme ....................................................

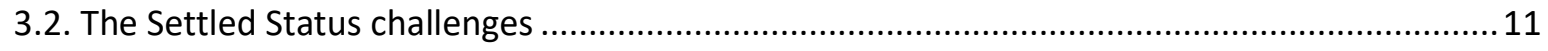

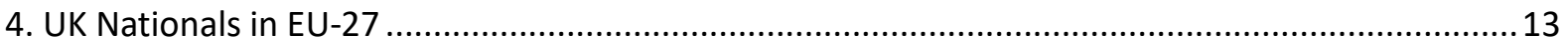

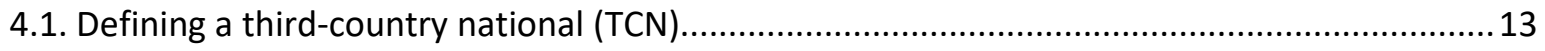

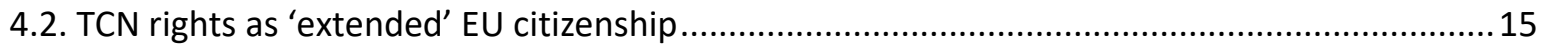

4.3. Privileged TCNs: EU Association and Partnership Agreements ............................................ 18

4.4. 'Show Me Your Money': TCN Investors ................................................................................... 19

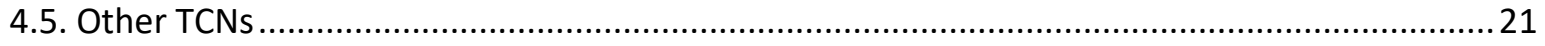

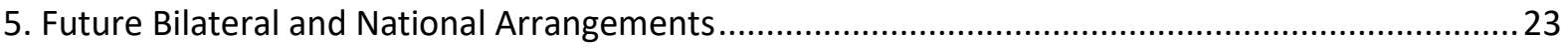

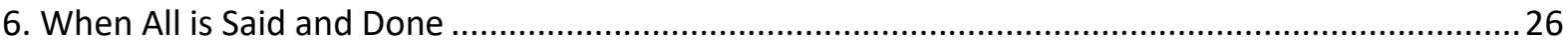

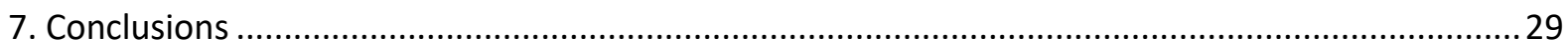


And I have promised to bring you up out of your misery [...]

into the land [...] flowing with milk and honey ${ }^{1}$

\section{Introduction}

As Brexit continued to unravel, many migrant EU citizens, both in the UK and outside the country, were waiting for the European Commission and the UK government to reach an agreement on their rights. During this time, grassroots civic organisations such as the3million, New Europeans and the British in Europe continued to lobby for securing EU citizens' rights at home and abroad, with many UK based EU nationals voting with their feet ${ }^{2}$ or obtaining more 'useful' passports, while the Irish nationals and those in Northern Ireland were worried about the Northern Irish border and the continuity of peace and the fate of the Good Friday Agreement. In the whirlpools of the Westminster Parliament, somewhere lost was the draft Withdrawal Agreement, which, despite the previous EU-UK negotiations, hung stuck among political disagreements and calls for 'better options' for the free and independent Great Britain, ${ }^{3}$ holding the lives of people and businesses in custody. With the new Prime Minister elected, the UK Government seems to be gearing up towards a no-deal Brexit, building up the current preparations, amidst the concerns over the overstretched civil service.

It is this complex socio-political context that informed the key research question of this chapter: what rights and legal protection will 5 million mobile EU citizens ${ }^{4}$ have when

\footnotetext{
* Senior Lecturer in Law at Anglia Ruskin University and Fellow at the Centre of European Law at King's College London. I am thankful to the book's editors for a very thorough and helpful peer review process that helped improve this chapter, which was completed on 5 September 2019.

${ }^{1}$ The Bible, Exodus 3:17.

${ }^{2}$ Office for National Statistics, 'Migration Statistics Quarterly Report: February 2019' (Office for National Statistics)

<https://www.ons.gov.uk/peoplepopulationandcommunity/populationandmigration/internationalmi gration/bulletins/migrationstatisticsquarterlyreport/february2019> accessed 17 March 2019.

3 See Patrick Birkinshaw and Andrea Biondi, Britain Alone! The Implications and Consequences of United Kingdom Exit from the EU (Wolters Kluwer 2016).

4 In 2017, an estimated 3,813,000 EU citizens were living in the UK, including the children born there: Carlos Vargas-Silva and Mariña Fernández-Reino, 'EU Migration to and from the UK' (2018) <https://migrationobservatory.ox.ac.uk/resources/briefings/eu-migration-to-and-from-the-uk/>
} 
they become third country nationals in the post-Brexit EU? What legal guarantees - if any could they rely upon under the current legal framework of European, national and international law? How far would such a framework protect the rights that have been developed as core status of the European Citizenship? If these rights cannot be retained, what do such legal realities tell us not only about the fragility of the EU citizenship as an idea, but also its longevity and even future survival in the world where liberal democracies are being challenged by fake news and the rise of nationalism?

Some of these questions have been raised by scholars, 5 but the ground for further reflections remains fertile. Losing transnational citizenship due to Brexit leaves a vacuum between national and international rules, which may or may not offer some protection to people who will lose EU citizenship status. ${ }^{6}$ This vacuum - from EU legislation perspective means that EU migration and asylum law will apply only to non-EU citizens and only in the manner prescribed by EU legislation which often has a 'limited equal treatment clause'.7 In other words, the loss of EU citizenship for UK nationals in EU-27 is likely to mean the end of strong equal treatment protection they had benefitted from under the EU free movement law, unless similar rights are guaranteed by future national legislation or international agreements.

accessed 18 March 2019. According to 2015 data, at least 1.2 million UK nationals currently reside in other EU Member States: United Nations Global Migration Database, 'International Migrant Stock by Destination and Origin'

<http://www.un.org/en/development/desa/population/migration/data/estimates2/estimates15.asp> accessed 16 March 2019.

5 For an excellent outlook, see the special issue of NILQ: Dagmar Schiek, 'On the Never-Ending Road to Brexit: Perspectives for the European Union - Introducing This Special Issue' (2018) 69 Northern Ireland Legal Quarterly 221.

${ }^{6}$ Francesca Strumia, 'European Citizenship and Transnational Rights: Chronicles of a Troubled Narrative' in Daniel Thym (ed), Questioning EU Citizenship: Judges and the Limits of Free Movement and Solidarity in the EU (Hart Publishing 2017) 166-167.

7 Sara Iglesias Sánchez, 'The Constitutional Status of Foreigners and European Union Citizens: Loopholes and Interactions in the Scope of Application of Fundamental Rights' in Daniel Thym (ed), Questioning EU Citizenship: Judges and the Limits of Free Movement and Solidarity in the EU (Hart Publishing 2017) 260. For a detailed review, see Sonia Morano-Foadi and Karin de Vries, 'The Equality Clauses in the EU Directives on Nondiscrimination and Migration/Asylum' in Sonia MoranoFoadi and Micaela Malena (eds), Integration for Third-Country Nationals in the European Union. The Equality Challenge (Edward Elgar 2012). 
This chapter builds on the above debates and goes further, drawing together the various doctrinal and normative arguments about EU citizenship post-Brexit, providing a broad birds-eye view of the legal protection of UK nationals in the EU and EU nationals in the UK, assessing the present regulation of their rights and suggesting ways forward for the future. To achieve this, we will briefly consider the development of EU Citizenship before Brexit (section 2) and proceed to assess the post-Brexit legal framework of EU citizenship rights at the international, EU and national levels, focusing on the protection of the rights guaranteed for the EU citizens in the UK (section 3) and British nationals in EU-27 (section 4). Overall, the chapter challenges the view of EU citizenship as a stand-alone political and legal status, concluding that the normative view of Union citizenship which seemed to offer much hope in the 'golden age' era of the Court of Justice's case law has been abandoned (section 6). At this stage of European integration, Union citizenship cannot be extended by the concept of acquired rights, it continues to be tied to Member State nationality and woven into the strict black-letter-law wording of EU legislation (section 7).

\section{When EU Citizenship Met Brexit}

The story of EU citizenship has been told by many and in most engaging ways, ${ }^{8}$ and its relationship with Brexit is only one of the key moments of its young existence of 26 years since Maastricht. Built on the foundations of the narrative of free movement as a migration discourse, 9 this supranational legal status, which displays cosmopolitan features, could be seen to represent the 'hollowing of national citizenship on the one hand and the rise of the

\footnotetext{
${ }^{8}$ E.g. Eleanor Spaventa, 'Seeing the Woods despite the Trees? On the Scope of Union Citizenship and Its Constitutional Effects' (2008) 45 Common Market Law Review 13; Alina Tryfonidou, The Impact of Union Citizenship on the EU's Market Freedoms (Hart Publishing 2016); Dimitry Kochenov (ed), EU Citizenship and Federalism: The Role of Rights (Cambridge University Press 2017); Adrienne Yong, The Rise and Decline of Fundamental Rights in EU Citizenship (Hart Publishing 2019).

9 When comparing the rights of EU citizens and third country nationals in EU law, Strumia observes that international law gives an unfettered right for Member States to determine their own migration policies. Considerations on how certain Member States monetize EU citizenship by offering 'golden passports' provide a good example on such 'nationalisation' of EU free movement rights. Hence losing transnational citizenship due to Brexit leaves a vacuum between national and international rules, which may or may not offer some protection to people who will lose EU citizenship status; see Strumia (n 7) $153,156-7,166-7$.
} 
cosmopolitan as a threatening alternative on the other, ${ }^{, 10}$ with the Brexit vote expressly rejecting the latter. Clearly, a pragmatic legal-political construct of Union citizenship differs from national citizenship because the Union 'has not established a sacrificial culture and has not turned domestic societies into societies of control and surveillance'. ${ }^{11}$ Despite this, the EU citizenship, as it is currently construed in EU Treaties, legislation and case law, has been criticised for driving the 'invisible legal wedge' between the haves (the mobile EU citizens) and the have nots (those who cannot afford or are unable to move), raising concerns of social justice, equality and social exclusion across borders. ${ }^{12}$ The recent cases on welfare benefit access across borders for non-economically active EU citizens, illustrate the opening gap of Europe's social deficit that fails to address also the issues of ethnic equality across borders. ${ }^{13}$ Thus critical perspectives on EU citizenship appraise it as too idealistic, too political, too unjust, ${ }^{14}$ a status that prioritises the freedoms of the selected few who can allow themselves to free movement.

As the story of EU citizenship is one very closely linked to migration and movement across borders, it is no surprise that one of the key political arguments behind the Brexit vote was about reducing immigration from the EU countries at all costs. To see the broader picture, we must recall that Europe's contemporary story of external immigration started after the Second World War, with increase of migrant workers before 1970 s oil crisis. At the

${ }^{10}$ Stephen Coutts, 'Citizens of Elsewhere, Everywhere and ... Nowhere? Rethinking Union Citizenship in Light of Brexit' (2018) 69 Northern Ireland Legal Quarterly 231, 232.

${ }^{11}$ Dora Kostakopoulou, 'Scala Civium: Citizenship Templates Post-Brexit and the European Union's Duty to Protect EU Citizens' (2018) 56 Journal of Common Market Studies 854, 857.

${ }^{12}$ Dimitry Kochenov, Graínne De Búrca and Andrew Williams (eds), Europe’s Justice Deficit? (Hart Publishing 2015); Charlotte O'Brien, Unity in Adversity: EU Citizenship, Social Justice and the Cautionary Tale of the UK (Hart 2017); Dimitry Kochenov and Timofey Agarin, 'Expecting Too Much: European Union's Minority Protection Hide-and-Seek' (2017) 1 Anti-Discrimination Law Review 7; Uladzislau Belavusau and Kristin Henrard (eds), EU Anti-Discrimination Law beyond Gender (Hart Publishing 2018).

${ }^{13}$ Egle Dagilyte and Margaret Greenfields, 'United Kingdom Welfare Benefit Reforms in 2013-2014: Roma between the Pillory, the Precipice and the Slippery Slope' (2015) 37 Journal of Social Welfare and Family Law 476; Egle Dagilyte, Adam Lazowski and Panos Stasinopoulos, 'The Importance of Being Earnest: Spelling of Names, EU Citizenship and Fundamental Rights' (2015) 11 Croatian Yearbook of European Law and Policy <http://www.cyelp.com/index.php/cyelp/article/view/233>.

${ }_{14}$ Elaine Fahey and Tawhida Ahmed, On Brexit: Law, Justices and Injustices (Edward Elgar Publishing 2019); Jakob Huber, 'EU Citizens in Post-Brexit UK: The Case for Automatic Naturalisation' (2019) o Journal of European Integration 1. 
time, family migration was the main way to settle in Europe and since then more restrictive national immigration policies have been introduced. ${ }^{15}$ While the intra-EU migration became regulated with the establishment of the 1957 Treaty on the European Economic Community, the European Union's independent immigration and asylum policy was introduced by the 1997 Amsterdam Treaty, which came after the introduction of EU citizenship by the Maastricht Treaty in 1992. Since Amsterdam, several regulations and directives were adopted, which are likely to apply to UK nationals post Brexit, unless special arrangements are made.

Today, EU citizenship is a special status that can be acquired only by holding a nationality of one of the Member States. ${ }^{16}$ Not only it guarantees non-discrimination based on nationality and the freedom of movement and residence, but a plethora of other rights that often result due to the combination of these two. Such rights include equal access to local labour market, education, healthcare, welfare benefits (with some limitations) and pensions, the right to vote in European Parliament elections, to propose EU legislation, and to obtain consular support abroad. While on the face of it - judging from Articles 20 and 21 TFEU - the EU citizenship has a very general personal and substantive scope, it is limited by the Citizenship Directive, ${ }^{17}$ which prescribes stronger rights for those who carry out economic activity or have sufficient resources and healthcare to live independently in another Member Sate. ${ }^{18}$

Despite these European developments, most immigration policies are still regulated at national level today, with several Member States - the UK, Ireland and Denmark - not being parties to the EU external immigration regime. Such legal regulation means there is

\footnotetext{
15 Pieter Boeles and others, European Migration Law (2nd edn, Intersentia 2014) 25-28.

${ }^{16}$ Article 2O(1) TFEU.

${ }_{17}$ Directive (EC) 2004/38 on the right of citizens of the Union and their family members to move and reside freely within the territory of the Member States [2004] OJ L158/77 38.

${ }^{18}$ Anne Wesemann, 'European Union Citizens in Post EU UK' in Karl August Sachsen Gessaphe, Nils Szuka and Juan J Garcia Blesa (eds), Legal Implications of Brexit (Fern Universität in Hagen 2018) 7.
} 
already a huge fragmentation ${ }^{19}$ of legal landscapes across the Union, especially when it comes to integration of immigrants and labour immigration of unskilled third country nationals. ${ }^{20}$ This fragmentation presents difficulties in evaluating future EU citizens' and UK nationals' rights after Brexit, especially as core EU citizenship rights relate to free movement, residence and non-discrimination.

Before proceeding to analyse the situation of UK nationals in EU-27, let us first consider current and future regulation of the rights of EU citizens in the post-Brexit UK, assessing what assurances - if any - the concept of EU citizenship may provide them.

\section{EU-27 Nationals in the Post-Brexit UK}

Brexit will cause reduction of EU citizenship rights not only for UK nationals, but also for EU citizens who currently reside or will arrive in the UK in the future. At the outset, however, we must acknowledge the special status of Irish nationals under UK migration law, who will have a more privileged status, as they will not be required to apply for legal recognition of residence due to the Common Travel Area arrangements. ${ }^{21}$ As for other non-Irish EU citizens in the UK, if the Withdrawal Agreement (WA) is not signed, their residence rights will have to be provided by UK national law, 'subject only to certain international human rights obligations. ${ }^{\prime 22}$

During negotiations of the WA, ${ }^{23}$ the UK Government kept referring to the 'special relationship' between the UK and the EU that is due to be preserved, whatever the outcome.

\footnotetext{
19 Oliver Garner, 'After Brexit: Protecting European Citizens and Citizenship from Fragmentation' [2016] EUI Working Paper LAW 2016/22.

20 Boeles and others (n 16) 29.

${ }^{21}$ Ben Warwick and Colin Murray, 'What Brexit Means for Future of the Common Travel Area between Ireland and the UK' The Conversation (26 February 2019) <http://theconversation.com/what-brexit-means-for-future-of-the-common-travel-area-betweenireland-and-the-uk-112312> accessed 6 May 2019.

${ }^{22}$ Huber (n 15) 2-3. Such obligations would include observing the right to family life under Article 8 ECHR, as outlined under the Kurić doctrine: Kurić and Others v Slovenia (13 July 2010), Application No. 26828/o6, paras 351 and 352. For commentary, see Annette Schrauwen, '(Not) Losing out from Brexit' (2017) 1 Europe and the World 1, 5-6.

23 Agreement on the withdrawal of the United Kingdom of Great Britain and Northern Ireland from the European Union and the European Atomic Energy Community [2019] XT 21028/19 19.
} 
One may ask whether such political and diplomatic declarations translate to a meaningful 'special status' for EU citizens in the UK post-Brexit or are they just mere rhetoric. What does the WA and Political Declaration ${ }^{24}$ say about the 'special status' of EU citizens in the UK and UK nationals in the EU?

The WA provisions allow for two options: preserving EU rights via a national application procedure (Article 18.1 WA), or a more simplistic declaratory procedure (Article 18.4 WA). By implementing the UK Settlement Scheme, ${ }^{25}$ the UK opted for a more demanding application procedure, which was fully rolled on 30 March 2019. Given that the Scheme remains the only certainty for the future protection of EU-27 rights in the UK, it is worth looking at it in more detail, to illuminate its successes (the UK Government view) and challenges (the civil society view) so far.

\subsection{The practical arrangements of the UK Settlement Scheme}

From the point of the Home Office (the Government department responsible for UK implementing migration policies), the UK Settlement Scheme seems to be going well. It was first piloted across twelve NHS Trusts and three universities, with 1,000 EU applicants taking part in the trial. ${ }^{26}$ The second pilot ${ }^{27}$ saw almost 30,000 applications submitted in November-December 2018, with some vulnerable applicants being supported by community advice organisations and charities. This second pilot included the EU Exit: ID Document Check app, which has been noted as problematic, not least because it was only available on

\footnotetext{
${ }^{24}$ Political Declaration setting out the framework for the future relationship between the European Union and the United Kingdom [2018] XT 21095/18 18.

${ }^{25}$ Home Office, 'EU Settlement Scheme: Applicant Information' (GOV.UK)

<https://www.gov.uk/government/collections/eu-settlement-scheme-applicant-information> accessed 6 August 2019.

${ }^{26}$ UK Home Office, 'Final EU Settlement Scheme - Private Beta Testing Phase 1 Report' (2018) $<$ https://www.gov.uk/government/publications/eu-settlement-scheme-public-beta-testing-phasereport/eu-settlement-scheme-public-beta-testing-phase-report> accessed 5 August 2019.

27 UK Home Office, 'EU Settlement Scheme - Private Beta Testing Phase 2 Report' (2019) $<$ https://www.gov.uk/government/publications/eu-settlement-scheme-public-beta-testing-phasereport/eu-settlement-scheme-public-beta-testing-phase-report> accessed 5 August 2019.
} 
Android and not on Apple devices, which is now being addressed. ${ }^{28}$ The purpose of the testing was to streamline how employment and tax data held by the public authorities is used to support Settlement Scheme applications.

The Scheme, for which the application charge has been removed, opened fully on 30 March 2019 and consists of three key steps: proving one's identity, showing that they live in the UK, and declaring any criminal convictions. It is open to all those currently here under EU law, including the non-EEA family members of EEA and Swiss citizens. ${ }^{29}$

According to the latest data, the total number of applications received up to 30 June 2019 was 909,300, with 805,500 decisions made (65\% have been awarded settled status, $35 \%$ pre-settled status and $0.3 \%$ faced 'other outcomes'). ${ }^{30}$ Polish, Romanian and Italian nationals have been most active to apply. ${ }^{11}$ Thus, in the eyes of the Home Office, EU citizens have a 'significant period of transition' time to apply and obtain settled or pre-settled status, ${ }^{32}$ i.e. until 2021, when the new border and immigration system will be introduced. 33 According to the Home Office's own surveys, user feedback on the online applications system, has also been positive, noting that the service is 'widely accessible' and 'great majority of users will not require any assistance', while those in need of help will be supported by a call centre. 34

${ }^{28}$ Sam Trendall, 'Home Office Holds Firm on Digital-Only Status for EU Settlement Scheme' PublicTechnology.net (25 July 2019) <https://www.publictechnology.net/articles/news/home-officeholds-firm-digital-only-status-eu-settlement-scheme> accessed 6 August 2019.

${ }^{29}$ Home Office, 'EU Settlement Scheme Statistics, June 2019' (2019) 3.

${ }^{30}$ Home Office, 'EU Settlement Scheme Statistics, June 2019' (n 30).

31 ibid 2.

${ }^{32}$ Settled Status is awarded to EU citizens who have resided lawfully and continuously in the UK for five years or longer prior to 31 December 2020. Pre-Settled status is awarded to those who resided for less than five years and it carries more limited residence rights than the Settled Status. For comparison, see Melissa Macdonald, 'EU Settlement Scheme' (2019) House of Commons Library Briefing Paper 8584 .

33 House of Commons Home Affairs Committee, 'EU Settlement Scheme: Government Response to the Committee's Fifteenth Report of Session 2017-19' (2019) HC 25929.

34 ibid. 


\subsection{The Settled Status challenges}

The approach that the UK has taken via the EU Settlement Scheme has been criticised by many, not just because it is an application - and not a declaratory - process at the end of which those who did not obtain a settled or pre-settled status will become illegal migrants on the UK soil. 35 Wider criticisms have been raised regarding the practical implementation aspects of the Scheme. ${ }^{36}$. Alternative proposals have been put forward including securing a no-deportation result for those who cannot apply before the short deadline of the Scheme. ${ }^{37}$ Political theorists called for the UK to allow fully-pledged automatic naturalisation rights for EU citizens resident before the Brexit vote, rather than treating them as permanent guests ${ }^{38}$ or live-in servants. ${ }^{39}$ Legal scholars argued for a less ambitious ‘EU protected citizen'40 or UK-EU citizenship ${ }^{41}$ status.

From the point of view of civil society, the biggest problem to date with the UK Settlement Scheme has been its personal scope: originally, it did not cover all types of persons that EU citizenship covered. ${ }^{22}$ Secondly, the passed national legislation allows for

\footnotetext{
35 Groups such as The3Million (a campaign group representing EU citizens in the UK) and the House of Commons Home Affairs Committee support a declaratory approach. See Nicola Newson, 'EEA Nationals (Indefinite Leave to Remain) Bill [HL] HL Bill 38 of 2017-19. House of Lords Library Briefing' (House of Lords Library 2019) Lords Library notes LLN-2019-0092.

${ }^{36}$ House of Commons Home Affairs Committee (n 34); the3Million, 'The UK EU Settlement Scheme (UKEUSS) - on the Ground'

<https://static.wixstatic.com/ugd/od3854_54946819c6b445cd9675b7e14d5f77d3.pdf> accessed 7 August 2019.

37 the3Million, 'EEA Nationals (Indefinite Leave to Remain) Bill - Briefing for Lords Second Reading. EU Settlement Scheme: From a Constitutive to Declaratory System' (2019).

${ }^{38}$ Huber (n 15) 7. This is similar to the fast-track nationality proposal by Susie Alegre, except the latter argues for retention of the previous nationality, resulting in larger numbers of EU citizens with dual nationalities: Georgia Austin-Greenall and Sylwia Lipinska, 'Brexit and Loss of EU Citizenship: Cases, Options, Perceptions' (ECAS 2017) 23 <http://ecas.org/wp-content/uploads/2017/12/Brexit-andLoss-of-EU-Citizenship-1.pdf> accessed 6 May 2019.

39 Michael Brookes, Spheres of Justice: A Defence of Pluralism and Equality (Basic Books 1983) 52.

${ }^{40}$ Kostakopoulou, 'Scala Civium: Citizenship Templates Post-Brexit and the European Union's Duty to Protect EU Citizens' (n 12).

${ }^{41}$ Wesemann (n 19) 21-25.

${ }^{42}$ Some accommodation has now been made for those with a derivative right to reside based on the CJEU judgments in Case C-34/o9 Ruiz Zambrano ECLI:EU:C:2011:124, Case C-200/o2 Chen ECLI:EU:C:2004:639, Case Ibrahim C-310/o8 ECLI:EU:C:2010:80 and Case Teixeira C-480/o8 ECLI:EU:C:2010:83: Home Office, 'EU Settlement Scheme: Derivative Right to Reside (Chen and Ibrahim/Teixeira Cases). Guidance for Caseworkers. Version 1.o'. Note that the Surinder Singh situations (returnees and their family members) and Lounes cases (dual British and EEA citizens) are
} 
greater discretion for UK migration bodies to remove/prevent from entering EU-27 nationals to its territory post-Brexit.43 Thirdly, considerations about vulnerable EU citizens and their access to the Settled Status remain high. ${ }^{44}$ For example, in the event of a no deal, EU citizens will be able to enter the UK to visit, work or study after 31 October 2019. For stays longer than 3 months, a newly introduced European Temporary Leave to Remain will be required. 45 In the fourth place, the concerns about the digital divide remain, as the Home Office continues to refuse issuing non-digital proof of status for those who obtained it (fearing the possibility of fraud and counterfeiting, or people being controlled in domestic violence, modern slavery and human trafficking situations), ${ }^{46}$ despite the call for this to be introduced by Parliament in the House of Commons Home Affairs Committee 47 and in the House of Lords European Union Committee. $4^{4}$

Overall, the Settled Status offers much more limited rights to non-Irish EU citizens in the post-Brexit UK: it 'focusses on the establishment of a new right to reside ... and as such moves even further away from the rights EU citizenship entails.'49

also covered: Home Office, 'EU Settlement Scheme: Written Statement - HCWS1387'. See Case C370/90 Surinder Singh, ECLI:EU:C:1992:296; Case C-165/16 Lounes, ECLI:EU:C:2017:862.

43 Conor James McKinney, 'How New Immigration Regulations Will Make It Easier to Deport EU Citizens after Brexit' Free Movement (13 March 2019) < https://www.freemovement.org.uk/how-newimmigration-regulations-will-make-it-easier-to-deport-eu-citizens-after-brexit/> accessed 17 March 2019.

44 Madeleine Sumption and Zovanga Kone, 'Unsettled Status? Which EU Citizens Are at Risk of Failing to Secure Their Rights after Brexit?' (COMPAS, University of Oxford 2018) Migration Observatory Report.

45 Home Office and UK Visas and Immigration, 'Government Outlines No Deal Arrangements for EU Citizens' (28 January 2019) <https://www.gov.uk/government/news/government-outlines-no-dealarrangements-for-eu-citizens $>$ accessed 28 August 2019.

${ }^{46}$ House of Commons Home Affairs Committee (n 34) 9-10.

47 Trendall (n 29).

${ }^{48}$ Baroness Kennedy of The Shaws, 'EU Settlement Scheme. Letter from the Chairman of EU Justice

Sub-Committee to Home Secretary' (27 February 2019)

$<$ https://www.parliament.uk/documents/lords-committees/eu-justice-

subcommittee/CWM/HKtoSJ-SettledStatus-260219.pdf> accessed 9 August 2019.

49 Wesemann (n 19) 12. 


\section{UK Nationals in EU-27}

Having considered the rights of EU citizens in the post-Brexit UK, let us now assess what future rights UK nationals will possess in Member States as third-country nationals (TCNs) and evaluate the implications the change of their rights may have to the concept of EU citizenship.

\subsection{Defining a third-country national (TCN)}

Vast differences exist between the rights awarded to EU citizens and TNCs by EU law and by EU international treaties between the EU and other countries. To begin with, even the definition of TCNs is not straightforward, highlighting that some categories of TCNs are more special than others. By default, a third-country national is defined as 'any person who is not a Union citizen within the meaning of Article 20 TFEU'. ${ }^{\circ}$ However, Boeles points to Article 2(6) of the Schengen Border Code that grants preferential treatment to the nationals of the countries who are part of the European Economic Area Treaty and the EU-Switzerland Agreement (Iceland, Liechtenstein, Norway, Switzerland). Thus, any distinction between EU citizens and non-citizens is nuanced and complex: not every person from a third country is treated the same by EU law, and some are awarded a 'special' status. ${ }^{51}$

Connecting EU citizenship and immigration law, Wiesbrock distinguishes four categories of TCNs, $5^{2}$ based on the extent of rights awarded to them in the EU. The first category is that of 'privileged' TCNs: family members of EU citizens who have made use of their free movement rights, hence their generous rights are governed by Directive 2004/3853 and the Regulation 492/2011.54 The second category is that of 'semi' privileged TNCs: family members of EU citizens who have not made use of their free movement rights in the EU

\footnotetext{
50 Boeles and others (n 16) 128.

51 ibid 37.

$5^{2}$ Anja Wiesbrock, Legal Migration to the European Union (Martinus Nijhoff 2010) 11, 93-161.

53 Directive (EC) 2004/38 on the right of citizens of the Union and their family members to move and reside freely within the territory of the Member States [2004] OJ L158/77.

54 Regulation 492/2011 on freedom of movement for workers within the Union [2011] OJ L141/1.
} 
('internal situations'), 55 hence their rights are governed by the national law of the state of residence. The third category contains those holding a certain nationality that is awarded preferential treatment in by specific agreements between their country of origin and the EU.56 The most generous treatment under these agreements is awarded to the nationals of Iceland, Liechtenstein, Norway (the EFTA states) and Switzerland (the Swiss agreements), followed by Turkish nationals (under the EU-Turkey agreements). ${ }^{57}$ The fourth category covers those legally resident in the EU (other than from the UK, Ireland or Denmark) and not covered by any of the above legal regimes. Such persons are governed by EU legislation on TCNs.

While the legal situation of EU-27 nationals in the UK is complex, a no-deal Brexit presents a future of even higher uncertainty for UK nationals travelling, working, studying or living in EU-27 states. ${ }^{8}$ Many commentators agree that negotiating a trade/partnership treaty between the UK and the EU will be complex and hence is likely to take time.59 During this period of negotiations, if the Withdrawal Agreement is not signed, UK citizens abroad

55 Stefano Montaldo, 'Freedom of Movement, Social Integration and Naturalization: Testing Reverse Discrimination in the Recent Case Law of the Court of Justice' (2018) 3 European Papers 1481.

${ }^{6}$ Dimitry Kochenov and Martijn van den Brink, 'Pretending There Is No Union: Non-Derivative Quasi-Citzenship Rights of Third-Country Nationals in the EU', Rights of Third-Country Nationals under EU Association Agreements, vol 9 (Brill / Nijhoff 2015).

57 Note there are other countries that have an agreement with the EU (Algeria, Morocco, Tunisia, Russia, Albania, North Macedonia, Montenegro, Andorra, San Marino, 79 countries of the African, Caribbean and Pacific Group of States) under which their nationals who work legally in an EU Member state are entitled to the same working conditions as the nationals of their host country, but their residence and movement rights are non-existent or fall short of those available to the nationals of the EFTA states and Switzerland. For example, the nationals of the European micro-states (Andorra, Monaco, San Marino) do not have access to the free movement of persons in the whole EU internal market and only benefit from bilateral arrangements with the neighbouring Member States: European Commission, 'Relations with the Principality of Andorra, the Principality of Monaco and the Republic of San Marino Options for Closer Integration with the EU (Communication)' (2013) $\mathrm{COM} / 2012 / 0680$ final/2.

${ }^{8}$ Schrauwen (n 23); Jo Shaw, 'Citizenship and Free Movement in a Changing EU: Navigating an Archipelago of Contradictions' in Benjamin Martill and Uta Staiger (eds), Brexit and Beyond: Rethinking the Futures of Europe (UCL Press 2018); Meghan Benton, Safe or Sorry? Prospects for Britons in the European Union after Brexit (Migration Policy Institute Europe 2017); Elspeth Guild, Steve Peers and Jonathan Kingham, 'After a Hard BREXIT - British Citizens and Residence in the EU' (2017) 31 Immigration, Asylum and Nationality Law 121.

59 See e.g. Christa Tobler, 'One of Many Challenges after "Brexit": The Institutional Framework of an Alternative Agreement - Lessons from Switzerland and Elsewhere?' (2016) 23 Maastricht Journal of European and Comparative Law 575; Herwig Verschueren, 'Scenarios for Brexit and Social Security' (2017) 24 Maastricht Journal of European and Comparative Law 367. 
will remain treated as TCNs under EU law, also heavily dependent on the mercy of host Member State regulation. Therefore, the absence of transitional legal arrangements between the UK and the EU means that the treatment of UK nationals will likely depend on three sources of legal rules from which their rights could be derived: national law of the host Member State; any bilateral agreements that the UK and the host State may have entered into; EU law (on e.g. long-term resident TCNs); any EU-UK arrangements on travel and short-term residence that may be reached before 31 October 2019. Let us consider each of the above TCN categories in turn, complementing them with TCN investors, who became more prominent after Wiesbrock's classification was introduced, in order to determine what rights may be afforded for UK nationals in the EU-27 post-Brexit.

\subsection{TCN rights as 'extended' EU citizenship}

The first category of privileged TCNs are TCN family members of EU citizens. They have derived residence, work and education rights under EU law, allowing UK nationals to benefit from such legal status post-Brexit. In this sense, one could argue that such 'extended' EU citizenship may benefit those who can be classified as 'family members' under Articles 2 and 3 of the Citizenship Directive. ${ }^{60}$ However, drawing a conclusion on whether one is a family member of an EU citizen, especially if they are a TCN, is not always a straightforward task. There are two key difficulties. Namely, the legal definition of a 'family member' under EU law is not clear-cut: there exist legal complexities regarding the situation of carers and dependents. ${ }^{61}$ Secondly, both the EU citizens and their TCN family member may be in what is called a purely internal situation (i.e. in factual circumstances where they had not moved to another EU Member State) that leaves them outside the scope of application of EU law.

\footnotetext{
${ }^{60}$ Directive (EC) 2004/38 on the right of citizens of the Union and their family members to move and reside freely within the territory of the Member States [2004] OJ L158/77 38.

${ }^{61}$ Nathan Cambien, 'EU Citizenship and the Right to Care' in Dimitry Kochenov (ed), EU Citizenship and Federalism: The Role of Rights (Cambridge University Press 2017).
} 
This means they will not be able to benefit from the EU citizenship rights because the latter are attached to de facto mobility.

In relation to internal situations, ${ }^{62}$ EU law allows Member States to treat their nationals less favourably than Union citizens who rely on EU law rights. ${ }^{63}$ Such legal treatment has been criticised as reversely discriminatory, devouring European citizenship of any meaningful free-standing status and 'separating Union citizens in differentiated regimes.' 64 Despite this, and the long line of cases calling for the genuine enjoyment of the substance of the rights of the EU citizenship granted under Article 20 TFEU, ${ }^{65}$ the Court of Justice remains faithful to the vertical balance of competences in the field of intra-Union migration established by the Treaties: for EU law to apply, a cross-border movement to another Member State is required.

The older CJEU case law in relation to internal situations indicated that EU citizenship had no substance and in effect was just another format of migration law that depends on one's nationality, family relationships with an EU citizen and the socio-economic ability to move across borders. However, there seems to be some light of hope on this matter and that in particular situations a cross-border movement requirement could be avoided. In the cases of $O \& B^{66}$ and $S \& G^{67}$ the Court clarified that returnees ${ }^{68}$ and frontier workers would be covered by the right not to be discriminated because of their previous movement, with EU law protection being extended to their family members. Similarly, as the Lounes case

\footnotetext{
${ }^{62} 115 / 78$ Knoors [1979] ECLI:EU:C:1979:31; C-132/93 Steen [1994] ECLI:EU:C:1994:254; Joined Cases C-64/96 and C-65/o6 Uecker and Jacquet [1997] ECLI:EU:C:1997:285; C-165/16 Lounes [2017] ECLI:EU:C:2017:862.

63 Montaldo (n 56) 1485.

64 Montaldo (n 56) 1484.

65 C-34/og Ruiz Zambrano [2011] ECLI:EU:C:2011:124; C-434/o9 McCarthy [2011]

ECLI:EU:C:2011:277; C-256/11 Dereci [2011] ECLI:EU:C:2011:734; C-133/15 Chavez-Vilchez [2017] ECLI:EU:C:2017:354; C-82/16 KA and Others [2018] EU:C:2018:308.

${ }^{66} C-456 / 12$ O\&B [2014] ECLI:EU:C:2014:135.

${ }^{67} C-457 / 12 S \& G$ [2014] ECLI:EU:C:2014:136.

68 Article 3(1) of Directive 2004/38 guarantees EU law protection only for those 'who move to or reside in a Member State other than that of which they are a national' (emphasis added).
} 
demonstrates, ${ }^{69}$ an EU citizen (and their TCN family members) who moved to another Member State and then naturalised by taking up its nationality 20 years later would be covered by EU law, i.e. not treated as being in purely internal situations. Similar reasoning would apply to those with double nationalities, who moved to live in one of the Member States of their nationality..$^{70}$ These cases, dating back to 2014-17, indicate that the Court is trying to find ways to identify the existence of a cross-border element, bringing several factually diverse situations under the realm of EU law, in order to avoid resorting to the internal situation doctrine.

While such outcomes may give hope to some of the UK nationals who are family members of EU citizens in EU27 after Brexit, clearly such piecemeal case-by-case judicial method falls short of what a revision of the Treaties could offer. Despite desirability for legal certainty that could be offered by revisions of EU primary law,71 EU Treaty revision is currently unlikely to happen, given the differing political preferences and national agendas on migration from within and outside the EU. Ultimately, even if UK nationals (TCNs) are classified as family members under the Citizenship Directive post-Brexit, and satisfy the cross-border requirement, they will become less protected, for example, regarding the retention of the right of residence in cases where their EU citizen family member dies or departs from the host Member State, ${ }^{72}$ or if there is a divorce, annulment of marriage or termination of registered partnership. 73 This further illustrates the downgrading of Union citizenship rights that will occur after Brexit when UK nationals will become TCNs in the EU.

\footnotetext{
${ }^{69}$ C-165/16 Lounes (n 64).

${ }^{70} C-541 / 15$ Freitag [2017] ECLI:EU:C:2017:432.
}

${ }^{71}$ Wesemann correctly observes that the Lisbon Treaty introduces Article 50 TFEU (a Member State's right to leave), but failed to make any amendments in this regard to Articles 20 and 21 TFEU (EU citizenship), thus leaving a gap in the existing primary law framework on how EU citizens' rights are to be protected in a Brexit-like situation: Wesemann (n 19) 13. On current political and legal impossibility to reform EU citizenship into a self-standing status, see Dimitry Kochenov, 'EU Citizenship and Withdrawals from the Union: How Inevitable Is the Radical Downgrading of Rights?' in Carlos Closa (ed), Secession from a Member State and Withdrawal from the European Union: Troubled Membership (Cambridge University Press 2017).

72 Compare Article 12(1) vs Article 12(2) of Directive 2004/38.

73 Compare Article 13(1) vs Article 13(2) of Directive 2004/38. 
To sum up, while UK nationals who are family members of EU citizens can benefit from derived rights as 'extended' EU citizenship, such legal status is not equivalent to that awarded to EU citizens directly and will constitute a reduction in the rights of residence, work, education or social assistance currently awarded to UK nationals as EU citizens.

\subsection{Privileged TCNs: EU Association and Partnership Agreements}

As mentioned earlier, not all TCNs are treated equally by EU law, hence another privileged category of TCNs are the nationals of Norway, Iceland, Liechtenstein, Switzerland or Turkey, all of whom are protected under international agreements with the EU. While nationals of these countries do not benefit from fully-fledged EU citizenship rights, they have been granted some rights that other TCNs have not. One example of their privileged status is the right to travel in the EU without visa restrictions, i.e. on the same legal basis as EU citizens do. This is because Regulation 2018/180674 harmonises the list of third countries whose citizens are required to be in possession of a visa in order to cross external borders of the European Union (negative list, Annex I to the Regulation), and of third countries whose nationals are exempt from this requirement (positive list, Annex II to the Regulation). ${ }^{75}$ The visa exemption for Norway, Iceland and Liechtenstein flows from the agreement in the European Economic Area. ${ }^{6}$ The no-visa regime for Swiss nationals stems from the EU Swiss agreement.77 These international agreements signed by the EU represent a more exclusive 'club' of national and European relations and may serve as aspirations for the future of UK's trade agreement with the EU, especially as a no-deal withdrawal is likely to put UK nationals

\footnotetext{
74 Regulation 2018/1806 listing the third countries whose nationals must be in possession of visas when crossing the external borders and those whose nationals are exempt from that requirement [2018] L 303/39.

75 Kay Hailbronner, EU Immigration and Asylum Law: Commentary on EU Regulations and Directives (Beck CH / Hart / Nomos 2010) 29-62.

${ }^{76}$ Decision 94/1/EC on the conclusion of the Agreement on the European Economic Area [1994] OJ L 1/1; Recital 6 of Regulation 2018/1806 listing the third countries whose nationals must be in possession of visas when crossing the external borders and those whose nationals are exempt from that requirement [2018] L 303/39.
}

77 OJ L114/6, 2002; Recital 7 of ibid. 
at a more disadvantageous position than, for example, Moroccans or Russians. ${ }^{78}$

Nevertheless, even if UK nationals' rights are protected in a similar way, this will not equate to the protection of EU citizenship rights that they possess pre-Brexit, which means they will lose some of the current rights they are entitled to under EU law.

\section{4. 'Show Me Your Money': TCN Investors}

A third category of privileged TCNs, not mentioned by Wiesbrock, concerns TCNs who can obtain the nationality of a Member State by taking part in a national investment scheme,79 in turn becoming EU citizens. Considerations on how certain Member States monetize EU citizenship by offering 'golden passports' and 'golden residences' provide a good example of the 'nationalisation' of EU free movement rights and raise ethical and social justice questions on whether EU citizenship should be for sale. ${ }^{80}$

As an alternative policy choice to EU citizenship by investment, there was a proposal for an Associate Citizenship. This idea originated in the European Parliament in 2016, suggesting to allow nationals of a former Member State to continue benefitting from the freedoms to live, work and travel within the EU and to vote in European elections if they pay a set fee to the EU budget. ${ }^{81}$ In this way, associate EU citizenship is very similar to the ‘citizenship-by-investment', raising similar reservations. In addition, the associate citizenship proposal, while creative and ambitious, has been criticised by Shaw as utopian

\footnotetext{
${ }^{78}$ Kochenov, 'EU Citizenship and Withdrawals from the Union: How Inevitable Is the Radical Downgrading of Rights?' (n 74) 3.

79 Jelena Džankić, 'Investment-Based Citizenship and Residence Programmes in the EU' (2015) EUI Working Paper RSCAS 2015/o8; Jelena Džankić, 'Immigrant Investor Programmes in the European Union (EU)' (2018) 26 Journal of Contemporary European Studies 64; Aline Tryfonidou, 'Citizenshipfor-Sale Schemes and EU Law: Can Third-Country Nationals Buy Their Way into Becoming Subjects of EU Law?' in Samo Bardutzky and Elaine Fahey (eds), Framing the Subjects and Objects of Contemporary EU Law (Edward Elgar Publishing 2017). See also the Commission's fact-finding study published in January 2019: Dimitry Kochenov, 'Investor Citizenship and Residence: the EU Commission's Incompetent Case for Blood and Soil' (Verfassungsblog, 23 January 2019) $<$ https://verfassungsblog.de/investor-citizenship-and-residence-the-eu-commissions-incompetentcase-for-blood-and-soil/> accessed 5 August 2019.

${ }^{80}$ Strumia (n 7) 156-157.

${ }^{81}$ Austin-Greenall and Lipinska (n 39); Schrauwen (n 23). For similar proposal for an 'EU protected citizen status', see Kostakopoulou, 'Scala Civium: Citizenship Templates Post-Brexit and the European Union's Duty to Protect EU Citizens' (n 12).
} 
and unpractical. ${ }^{82}$ Similarly, Kochenov and Van den Brink ${ }^{83}$ argue that it would go against the letter of Article $20 \mathrm{TFEU}, 84$ fail to respect reciprocity - key principle of international cooperation - in future EU-UK relations, 'potentially undermining the interests of EU citizens' 85 and would be undemocratic, especially in relation to political rights, ${ }^{86}$ creating a second-class EU citizenship. In their view, the doctrine of acquired rights ${ }^{87}$ - which is absent from the Treaties but features in the Court of Justice jurisprudence ${ }^{88}$ - cannot be interpreted too liberally, because doing so would put the effectiveness of EU law (Article 50 TFEU) in danger and could encourage more Member States to withdraw from the Union in the future. ${ }^{89}$ In support of their view, Schrauwen, too, notes that 'residence rights are not acquired rights, nor is there the possibility to enforce acquired rights.'9o Therefore, it seems that the concept of acquired rights cannot be used to extend the scope of EU citizenship as an independent status neither for UK nationals in the EU-27 nor for EU citizens in the UK after Brexit. This means that the loss of EU citizenship rights is inevitable once Britain leaves the Union.

\footnotetext{
${ }^{82}$ Shaw (n 60) 164.
}

83 Martijn van den Brink and Dimitry Kochenov, 'Against Associate EU Citizenship' [2019] JCMS: Journal of Common Market Studies <https://doi.org/10.1111/jcms.12898>.

84 According to Article 20 TFEU, EU citizenship is based on Member State nationality. This conclusion is supported, Kochenov and Van den Brink argue, by the case law of the Court of Justice: $C$-135/o8 Rottmann [2010] ECLI:EU:C:2010:104; C-369/9o Micheletti [1992] ECLI:EU:C:1992:295; C-192/99 Kaur [2001] ECLI:EU:C:2001:106. Thus 'citizenship of the Union, ... is intended to be the fundamental status of nationals of the Member States': C-82/16 K.A. and Others (n 68) para 47. 85 van den Brink and Kochenov (n 86) 8.

86 Federico Fabbrini, ‘The Political Side of EU Citizenship in the Context of EU Federalism' in Dimitry Kochenov (ed), EU Citizenship and Federalism: The Role of Rights (Cambridge University Press 2017).

87 Kostakopoulou, 'Scala Civium: Citizenship Templates Post-Brexit and the European Union's Duty to Protect EU Citizens' (n 12) 865; Thomas Donegan and Ellie Teo, 'Brexit: Free Movement of Persons' (2016) 31 Journal of International Banking Law and Regulation 565, 568-569; House of Lords European Union Committee, 'Brexit: Acquired Rights' (2016) HL Paper 82 25-28.

${ }^{88}$ See Joined Cases C-7/56 and C-3/57 to C-7/57 Algera and Others [1957] ECLI:EU:C:1957:7; Joined cases 42 and 49/59 SNUPAT [1961] ECLI:EU:C:1961:5; C-376/o2 Stichting 'Goed Wonen’ [2005] ECLI:EU:C:2005:251.

89 van den Brink and Kochenov (n 86) 10.

9o Schrauwen (n 23) 4. 


\subsection{Other TCNs}

Given that Article 20 TFEU will not be applicable on Brexit day, UK nationals in the EU who are not family members of EU citizens, investors or hold the nationality of a privileged state, but have lived there legally and continuously for five years or longer and would meet other required conditions (e.g. language requirements), would need to secure their residency rights based on the Long-Term TCN Residents Directive (hereafter TCN Residents Directive). ${ }^{11}$ There may be also other EU legislation that will become applicable to TCN UK nationals, ${ }^{92}$ and some of it will be unfamiliar to many UK immigration lawyers because of the current UK opt-outs. ${ }^{93}$ Thus, in preparation for no-deal, the Commission urged Member States by the withdrawal date to 'issue temporary residence documents, until definitive residence permits can be issued'94 under the TCN Residents Directive (for the UK nationals with at least five years of continuous legal residence) or to apply other EU or national law (for UK nationals who have resided in the host state for less than five years).

While falling back on the TCN Directive may be somewhat reassuring for the Brits living in the EU post-Brexit, this Union legislation does not offer the same rights as EU citizenship. To begin with, full free movement rights within the EU are only secured after one has been legally resident in one Member Sate for five years, ${ }^{95}$ and the Directive only allows absences from the EU of 12 months. ${ }^{96}$ The Directive's equal treatment provisions,

\footnotetext{
${ }^{91}$ Directive (EC) 2003/109 concerning the status of third-country nationals who are long-term residents [2003] OJ L16/44 109. For commentary, see Steve Peers, 'UK Citizens as Non-EU Citizens in the EU after Brexit: Applying the EU Directive on Non-EU Long-Term Residents' (EU Law Analysis, 27 December 2018) <http://eulawanalysis.blogspot.com/2018/12/uk-citizens-as-non-eucitizens-in-eu.html > accessed 5 August 2019. Note the Directive would not apply to UK nationals residing in Denmark and Ireland, as these Member States opted out from EU migration law provisions: Guild, Peers and Kingham (n 60) 128.

${ }^{22}$ Such as on the admission of students and researchers: Directive (EU) 2016/801 on the conditions of entry and residence of third-country nationals for the purposes of research, studies, training, voluntary service, pupil exchange schemes or educational projects and au pairing [2016] L 132/21 801. See Guild, Peers and Kingham (n 60) 123-124.

93 Guild, Peers and Kingham (n 6o) 121.

94 European Commission, 'Preparing for the Withdrawal of the United Kingdom from the European Union on 30 March 2019: Implementing the Commission's Contingency Action Plan' COM(2018) 890 final 4.

95 Article 4(1).

${ }_{96}^{6}$ Article 9.
} 
guaranteeing conditional rights ${ }^{97}$ to access to, for example, study grants, social assistance and tax benefits, ${ }^{8}$ have been viewed as short of those guaranteed under EU citizenship, too. 99 In addition, Under Article 5(2) of the Directive, the 'host Member States can demand compliance with national integration measures, request evidence of stable and regular resources, and can reject an application on grounds of public policy or public security.'100 Similarly, those UK nationals who move because they provide a service across borders (and do not seek employment) will find the rules under the Directive more restrictive ${ }^{101}$ than the current legal framework on establishment and free movement of services, or non-existent at EU level if they are self-employed.102

In terms of short-term residence and travel arrangements, the EU agreed visa-free travel for UK nationals. ${ }^{103}$ However, such travel will include border checks and passports being stamped, eventually turning into advance electronic checks, like those in the US Electronic System for Travel Authorisation (ESTA). This will mean that UK nationals between the ages of 18 and 70 will be liable to pay a small fee (7 euro) when entering the EU,

\footnotetext{
97 Article 4.

${ }_{98}$ Article 11.

99 Diego Acosta Arcarazo, The Long-Term Residence Status as a Subsidiary Form of EU Citizenship: An Analysis of Directive 2003/109 (Brill Nijhoff 2011) 109.

${ }^{100}$ Kostakopoulou, 'Scala Civium: Citizenship Templates Post-Brexit and the European Union's Duty to Protect EU Citizens' (n 12) 860.

${ }^{101}$ Article 14 ff.

${ }^{102}$ Guild, Peers and Kingham (n 60) 126.

${ }^{103}$ Article 4.1 of Regulation 2018/1806 waives a visa requirement for "no more than 90 days in any 180-day period", exempting UK nationals from visa requirements, provided that all Union citizens are equally exempted from UK visa requirements: Regulation 2018/1806 listing the third countries whose nationals must be in possession of visas when crossing the external borders and those whose nationals are exempt from that requirement [2018] L 303/39. This Regulation should be read in line with Regulation (EU) 2016/399 of the European Parliament and of the Council of 9 March 2016 on a Union Code on the rules governing the movement of persons across borders (Schengen Borders Code) [2016] OJ L77/1. For commentary on the latter, see Guild, Peers and Kingham (n 60) 122.
}

Regulation 2019/592 amending Regulation 2018/1806 listing the third countries whose nationals must be in possession of visas when crossing the external borders and those whose nationals are exempt from that requirement, as regards the withdrawal of the United Kingdom from the Union [2019] OJ L1O3/1. 
as part of the new European Travel Information and Authorisation System that is expected to strengthen security checks and to come into force in $2021 .{ }^{104}$

Another relevant piece of EU legislation is the Family Reunification Directive:105 applicable 'when the TCN family member has an autonomous right of residence and can act as sponsor for family reunification.' ${ }^{106}$ Conditions for family reunification under this Directive are more stringent as compared to the generous rules under the Citizenship Directive, discussed above.

Finally, those UK nationals who may not have resided for five years and wish to work in a relevant Member State, after Brexit may rely on several other legislative instruments that regulate their worker/resident status, which in some cases may be time-limited. ${ }^{107}$

\section{Future Bilateral and National Arrangements}

Certain transitional arrangements and some form of 'settled status' are being made available not just to the three million non-UK EU nationals in the UK via the EU Settlement Scheme, ${ }^{108}$ but also to the 1.3 million UK nationals residing in the remaining 27 Member

\footnotetext{
104 European Commission, 'Security Union: A European Travel Information and Authorisation System - Questions \& Answers' (2018) MEMO/18/4362. For commentary on the historical and policy background of this legislation, see Guild, Peers and Kingham (n 60) 123.

105 Directive (EC) 2003/86 on the right to family reunification [2003] OJ L 251/12 12.

106 Schrauwen (n 23) 9.

${ }_{107}$ Directive (EC) 2009/50 on the conditions of entry and residence of third-country nationals for the purposes of highly qualified employment [2009] L155/17; Directive (EU) 2014/66 on the conditions of entry and residence of third-country nationals in the framework of an intra-corporate transfer [2014] L157/1; Directive (EU) 2016/801 on the conditions of entry and residence of third-country nationals for the purposes of research, studies, training, voluntary service, pupil exchange schemes or educational projects and au pairing [2016] L 132/21; Directive (EU) 2014/36 on the conditions of entry and stay of third-country nationals for the purpose of employment as seasonal workers [2014] L 94/375 36 .

108 The estimates from the Labour Force Survey for the period October - December 2018 show that there were an estimated 2.27 million EU nationals working in the UK, see Office for National Statistics (n 3) 6 .
} 
States. ${ }^{109}$ In addition, on the no-deal Brexit day, some old bilateral agreements that in the past were rendered void by the entry into force of EU Treaties and legislation may become applicable again. Most likely, they will need to be updated, perhaps re-negotiated. Such situation may occur, for example, with cross-border social security rights protection. ${ }^{110}$

The EU Commission's Communication on contingency planning issued in December $2018^{111}$ confirmed that without legislative intervention at individual state level, many of the UK nationals abroad would become 'illegal' on 31 October 2019. Unsurprisingly, initially there were a plethora of various responses from individual Member States how to avoid friction to trade and free movement after the 'Exit Day'. ${ }^{112}$ These ranged from plans to arrange special queues for UK nationals in Portuguese airports, ${ }^{113}$ to offering ten-year residence permits that protect acquired rights in Malta, ${ }^{114}$ or the promises to guarantee social security rights in Germany. ${ }^{115}$ The circumstances, for example, in the British Overseas Territory of Gibraltar ${ }^{116}$ and the British Crown Dependency of the Isle of Man bring their own

109 'Brits Abroad: How Many People from the UK Live in Other EU Countries?' Full Fact (1 February 2018) <https://fullfact.org/europe/how-many-uk-citizens-live-other-eu-countries/> accessed 17 March 2019.

${ }^{110}$ Verschueren (n 61) 379.

${ }^{111}$ European Commission, 'Preparing for the Withdrawal of the United Kingdom from the European Union on 30 March 2019: Implementing the Commission's Contingency Action Plan' (n 97).

112 For an updated overview on each Member State, see European Commission, 'UK Nationals' Residence Rights in the EU27' (2019) <https://ec.europa.eu/info/brexit/brexitpreparedness/citizens-rights_en> accessed 30 July 2019. For media coverage, see e.g. Eline Schaart, 'Citizens' Rights for Brits in the EU If There's No Brexit Deal' Politico (31 January 2019) <https://www.politico.eu/article/citizens-rights-for-brits-in-the-eu-if-theres-no-brexit-deal/> accessed 17 March 2019; Claudia Delpero, 'Residence, Citizenship, Social Benefits: What Changes for British Residents in the EU - Part 2' Europe Street News (12 February 2019) 2 $<$ https://europestreet.news/residence-citizenship-social-benefits-what-changes-for-british-residentsin-the-eu-part-2/> accessed 17 March 2019.

${ }_{113}$ Jon Henley, 'Portugal Plans Special Lanes for Britons in Airports after Brexit' The Guardian (17 January 2019) <https://www.theguardian.com/world/2019/jan/17/portugal-plans-special-lanes-forbritons-in-its-airports-after-brexit> accessed 17 March 2019.

114 Chris Scicluna, 'Malta to Offer Britons Renewable 10-Year Residency Permits' Reuters (23 January 2019) <https://www.reuters.com/article/us-britain-eu-malta-idUSKCN1PH1ON> accessed 17 March 2019.

115 Claudia Delpero, 'Brexit: Germany to Guarantee Social Security Rights in No Deal Preparations' Europe Street News (16 December 2018) <https://europestreet.news/brexit-germany-to-guaranteesocial-security-rights-in-no-deal-preparations/> accessed 18 March 2019.

${ }^{116}$ See Article 1 of the Protocol on Gibraltar attached to the Withdrawal Agreement and Notes for Interpretation of all Memoranda agreed between the Spain, the UK and Gibraltar on 29th November 2018. 
complexities, as these territories may have same UK nationality laws but separate immigration regulation or application of EU law. ${ }^{117}$ In the case of no-deal Brexit, British nationals (Overseas), British overseas territories citizens (BOTC), British overseas citizens (BOC), British protected persons (BPP,) British subjects (BS) are all excluded from the requirement to hold a visa for short-term travel via the newly adopted Regulation 2019/592. ${ }^{118}$ Despite the Commission's coordination work with the 27 Member States, states remain mostly free to adopt an approach that would suit 'their legal and administrative systems'119 and reflect the number of UK nationals resident on their territory, resulting in a varied landscape of residence regimes.

As Kochenov observes, ${ }^{120}$ it can be tempting for the UK to address bilateral agreements first with those Member States where most UK nationals currently reside (e.g. Spain), or with those that are economically advanced and hence do not pose the risk of attracting future immigration. Hence it is not surprising that the UK signed international agreements with Switzerland, Norway and Iceland to protect each other's citizen rights, ${ }^{121}$ with rights of Irish citizens being protected under the Common Travel Area arrangements. However, such bilateral agreements are problematic in terms of EU citizenship rights, as

\footnotetext{
${ }_{117}$ The UK's EU membership extends to include Gibraltar, but not the Isle of Man: see Protocol No. 3 to the Act of Accession which formed part of the United Kingdom's Treaty of Accession 1972. With regard to Gibraltar, see Recital 4 of Regulation 2019/592 amending Regulation 2018/1806 listing the third countries whose nationals must be in possession of visas when crossing the external borders and those whose nationals are exempt from that requirement, as regards the withdrawal of the United Kingdom from the Union [2019] OJ L103/1 592. The persons who have acquired their British overseas citizenship from a connection with Gibraltar (and hence are exempt from short-term visa requirement) are listed along with other British overseas territories (Anguilla, Bermuda, British Antarctic Territory, British Indian Ocean Territory, British Virgin Islands, Cayman Islands, Falkland Islands, Montserrat, Pitcairn, Saint Helena, Ascension and Tristan da Cunha, South Georgia and South Sandwich Islands and Turks and Caicos Islands) in Annex II Part 3 of Regulation 2018/1806 listing the third countries whose nationals must be in possession of visas when crossing the external borders and those whose nationals are exempt from that requirement [2018] L 303/39.

${ }_{118}$ Annex II Part 3 of Regulation 2018/1806, as amended by Articles 1(3) and (4) of Regulation $2019 / 592$.

119 European Commission, 'State of Play of Preparations of Contingency Measures for the Withdrawal of the United Kingdom from the European Union' COM(2019) 276 final 4.

${ }^{120}$ Kochenov, 'EU Citizenship and Withdrawals from the Union: How Inevitable Is the Radical Downgrading of Rights?' (n 74).

${ }^{121}$ Claudia Delpero, 'UK Agrees with Switzerland, Norway, Iceland to Protect Citizens' Rights Regardless of Brexit Deal' Europe Street News (10 February 2019) < https://europestreet.news/ukswitzerland-agree-post-brexit-residents-rights-regardless-of-eu-deal/> accessed 9 February 2019.
} 
they are done on the basis of each national state's capacity, with EU citizenship playing a role indirectly or not being considered at all. ${ }^{122}$ In the context of the EEA, the concept of Union citizenship is explicitly excluded from the scope of this agreement, ${ }^{123}$ which evidences that agreeing specific rights of free movement does not equal to the richer protection of rights guaranteed for EU citizens.

\section{When All is Said and Done}

Losing the rights attached to EU citizenship will be a big loss both to the EU-27 nationals in the UK and the UK nationals residing in the EU-27. As this chapter demonstrated, there are stark differences in EU citizens' and TCNs' rights' protection, ${ }^{124}$ depending on the overall EU competences, one's nationality and residence, work, migration, legal status. Typically, EU migration and asylum law often has a limited general treatment clause, ${ }^{125}$ which is less generous than EU citizenship legislation, widening the gap between the rights of EU citizens and TCNs.

Brexit has done away with the concept of vested or acquired rights ${ }^{126}$ that could be passportable throughout the Union. Without an alternative legal framework guaranteeing legal protection, and without a signed Withdrawal Agreement, many of those caught up in between will have to make a hard choice whether to uproot themselves and their families from the relevant host Member State, in order to protect, for example, the acquired social

\footnotetext{
122 Kochenov, 'EU Citizenship and Withdrawals from the Union: How Inevitable Is the Radical Downgrading of Rights?' (n 74) 30.

${ }^{123}$ Decision of the EEA Joint Committee No 158/2007 of 7 December 2007 amending Annex V (Free movement of workers) and Annex VIII (Right of establishment) to the EEA Agreement [2008] OJ L124/20, Recital 8. See also Donegan and Teo (n 90) 567-568.

124 Iglesias Sánchez (n 8).

125 ibid 256.

${ }^{126}$ Jan-Jaap Kuipers, 'Cartesio and Grunkin-Paul: Mutual Recognition as a Vested Rights Theory Based on Party Autonomy in Private Law' (2009) 2 European Journal of Legal Studies 66; Coutts (n 11) $237-238$.
} 
security rights, such as pensions, ${ }^{127}$ or whether to seek a more 'convenient' nationality via naturalisation or other available means (e.g. ancestry).

Such plethora of legal regulations and the fragmented landscape of rights is problematic not only to those who will move across European and UK borders after Brexit. It is 'a deeply problematic practice from the point of view of non-discrimination and the basic idea of European unity. ${ }^{128}$ They indicate that any European unity on the matter may be just an illusion, with wide margin of discretion left in the hands of national regulation when it comes to matters of nationality, political membership and the welfare state. One such trend, for example, is the discretion that the Court of Justice leaves to Member States when determining how integrated a foreigner must be before they can claim social rights. The EU citizenship cases on this point have received extensive commentary, ${ }^{129}$ and so have the TCNs cases where national law that makes social rights entitlement conditional to compulsory participation in integration programmes is considered justified. ${ }^{130}$ Making social rights conditional on a certain length of residence or financial contribution is a commonality that is likely to be retained by most Member States, especially as migration flows increase, borders continue to remain porous, and free movement continues to be closely associated with economic activity. ${ }^{131}$

Such more demanding conditions of integration for accessing welfare rights in the country of residence are likely to be strengthened by other - cultural, national identity conditions ${ }^{132}$ with which foreigners will be increasingly required to comply. Additionally,

${ }^{127}$ Helen McCarthy, 'The End of the Retirement Dream? British Pensioners in the European Union after Brexit' (2018) 10 MPI Europe Brief 1.

${ }^{128}$ Kochenov, 'EU Citizenship and Withdrawals from the Union: How Inevitable Is the Radical Downgrading of Rights?' (n 74).

129 C-140/12 Brey [2013] ECLI:EU:C:2013:565; C-333/13 Dano [2014] ECLI:EU:C:2014:2358; C67/14 Alimanovic [2015] ECLI:EU:C:2015:597; C-299/14 García-Nieto [2016] EU:C:2016:114; C308/14 Commission $v$ UK [2016] ECLI:EU:C:2016:436.

${ }^{130}$ See the cases discussed in Karin De Vries, 'The Integration Exception: A New Limit to Social Rights of Third-Country Nationals in European Union Law?' in Daniel Thym (ed), Questioning EU Citizenship: Judges and the Limits of Free Movement and Solidarity in the EU (Hart Publishing 2017) 267.

${ }^{131}$ Shaw (n 6o).

${ }_{132}$ De Vries (n 142) 270. 
Member States, such as Lithuania, which recently considered allowing a second nationality for Lithuanian nationals, cautiously proposed to do so only on the condition that such new national allegiance does not contradict the national values and the international pro-Western commitments of the Lithuanian state, ${ }^{133}$ in this way enforcing certain values for any Lithuanians with double nationalities.

Similar retreat to the national competence is also seen in the right to family life context. One only needs to compare the Court's reasoning in the Carpenter decision ${ }^{134}$ of 2002 and the $S \& G^{135}$ and $O \& B{ }^{136}$ cases in 2014. In the latter, the Court ruled on the basis of the Directive 2004/38, stating that the EU citizen's movement to a host Member State should be 'genuine' (i.e. holidays and weekends do not count), in order for derived residence rights to be created for a TCN who is a family member of the EU citizen; and that such movement should enable the EU citizen to 'create or strengthen' family life. ${ }^{137}$ Thus, it may be easier to demonstrate the 'effective exercise of the fundamental freedom guaranteed by Article 45 TFEU' if childcare to EU citizen's children was provided directly by their TCN spouse, as opposed to the TCN spouse's parents..$^{138}$ Such judicial retreat to black-letter law (literal) interpretation of the Citizenship Directive and restrictive interpretation of Articles 45 and 21(1) TFEU raise questions to what extent the CJEU may be willing to act as a protector of all mobile EU citizens' and their TCN family member's rights post-Brexit. Are EU citizens in the UK and EU-27 going to be treated less like citizens, more like migrants?

As for the UK, without delay it will have to shape its own migration policy. One suggestion is to adopt a 'managed movement' approach, which would allow to have a break

\footnotetext{
133 Despite this, the referendum in May 2019 rejected such a proposal, and a new generation of expatriate Lithuanians remain restricted to one passport only: LRT, 'Lithuania's citizenship referendum: necessary but rushed vote' lrt.lt (8 May 2019) < https://www.lrt.lt/naujienos/news-inenglish/19/1056843/lithuania-s-citizenship-referendum-necessary-but-rushed-vote > accessed 6 August 2019.

${ }_{134}$ C-6o/oo Carpenter [2002] ECLI:EU:C:2002:434.

${ }_{135} C-457 / 12 S \& G$ (n 70).

${ }^{136} C-456 / 12 O \& B$ (n 69). For commentary, see Boeles and others (n 16) 76-77.

${ }_{137} C-456 / 12$ O\&B (n 69) paras 56, 59.

${ }^{138} C-457 / 12 S \& G(\mathrm{n} 70)$ paras $42-44$.
} 
clause when a sudden influx of migration occurs, building on the emergency break clauses available under 'Article 112 of the European Economic Area (EEA) Treaty, the Liechtenstein Protocol, and the Swiss agreement giving priority for local hires.' ${ }^{139}$ Similarly, another proposal, which draws on the comparison of the EU rights of free movement and the EEA law, is to introduce certain intra-European migration controls, like the ones proposed in the pre-Brexit Cameron deal ${ }^{140}$ that are in place for Liechtenstein. ${ }^{141}$ The White Paper on UK Immigration that sets out UK's post-Brexit immigration system was published at the end of 2018,,$^{142}$ and it remains to be seen how Prime Minister Boris Johnson directs his government to take it forward.

\section{Conclusions}

The future both for the UK and for the EU looks less like a promised land of milk and honey and more of an enchanted forest, inhabited by 'monsters' of complex legal rules and 'witches' of fast-changing political priorities. Looking from a broader perspective, the loss of EU citizenship rights for those living in the UK may not be as problematic, as compared to UK nationals in EU-27. The former are to lose EU citizenship in the territory of one ex-Member State, while the latter will lose it forever and will fall under a different set of rights, regulated by the increasingly more complex legal landscape - until the new future agreement between the UK and the EU is reached. ${ }^{143}$

\footnotetext{
139 Catherine Barnard and Sarah Fraser-Butlin, 'Free Movement vs. Fair Movement: Brexit and Managed Migration' (2018) 55 Common Market Law Review 203.

${ }^{140}$ For critical assessment of the deal, see Stephanie Reynolds, '(De)Constructing the Road to Brexit: Paving the Way to Further Limitations on Free Movement and Equal Treatment?' in Daniel Thym (ed), Questioning EU Citizenship: Judges and the Limits of Free Movement and Solidarity in the EU (Hart Publishing 2017).

${ }^{141}$ Donegan and Teo (n 90).

${ }^{142}$ HM Government, 'The UK’s Future Skills-Based Immigration System' (2018). For assessment and recommendations, see Heather Rolfe, 'Challenges for Immigration Policy in Post-Brexit Britain: Introduction' (2019) 248 National Institute Economic Review R1 and other contributions in the same special issue of this journal.

143 One of the suggested options for the future UK-EU relationship was the Swiss model. However, it is not without trouble: the events since 2014 illustrate that the free movement and financial industry access to the EU market are thorny issues over which both parties are still having disagreements in order to reach a wide framework agreement to replace the existing 120 bilateral sectoral treaties. See
} 
There are no easy solutions for the future of EU citizens in the UK and UK nationals in the EU-27. Some scholars have suggested creating a new citizenship status, ${ }^{144}$ while others proposed a 'EU protected citizen' status, ${ }^{145}$ automatic naturalisation ${ }^{146}$ and even laissezpasser European passports. ${ }^{147}$ None of these options are without their criticisms, and to date they failed to appeal to the good will either of the European Commission or the UK Government.

The legal and political matters underpinning Brexit demonstrate that European citizenship seems to remain just 'a shadow of nationality'148 of the Member States. It is very far away from the normative ideal of society with communities of 'concern and engagement', where equality, political and welfare rights would be all-inclusive and protected as such at transnational level. ${ }^{149}$ While short of this ideal, the legal-political Union citizenship is much more than a mere residence status; it is rich with political, social rights and rights extended to EU citizens' family members. Seeing it reduced to a set of migratory rules by the various

Clive Church, 'What Is the Swiss Model of Co-Operation with the European Union?' The Conversation (6 May 2016) <http://theconversation.com/what-is-the-swiss-model-of-co-operation-with-theeuropean-union-58817> accessed 6 May 2019; Francesco Guarascio, 'UPDATE 2-EU Grants SixMonth Reprieve to Swiss Exchanges, Wants New Treaty' Reuters (17 December 2018) <https://www.reuters.com/article/swiss-eu-idUSL8N1YM28W> accessed 6 May 2019; Susan Misicka, 'What Is This EU Framework Deal?' SWI swissinfo.ch (1 April 2019) <https://www.swissinfo.ch/eng/politics/swiss-eu-relations_what-is-this-eu-framework-deal/44865230> accessed 6 May 2019.

144 Wesemann (n 19).

145 Kostakopoulou (n 66).

${ }^{146}$ Huber (n 15) 7.

147 Oliver Garner, 'The European Citizens Initiative on a European Free Movement Mechanism: A New Hope or a False Start for UK Nationals after Brexit?' (European Law Blog, 23 February 2017) $<$ https://europeanlawblog.eu/2017/02/23/the-european-citizens-initiative-on-a-european-freemovement-mechanism-a-new-hope-or-a-false-start-for-uk-nationals-after-brexit/> accessed 31 July 2019.

148 Austin-Greenall and Lipinska (n 39) 5.

149 Dora Kostakopoulou, 'Towards a Theory of Constructive Citizenship in Europe' (1996) 4 Journal of Political Philosophy 337; Dora Kostakopoulou, Citizenship, Identity, and Immigration in the European Union: Between Past and Future (Manchester University Press 2001); Maurizio Ferrera, 'The JCMS Annual Lecture: National Welfare States and European Integration: In Search of a "Virtuous Nesting"' (2009) 47 Journal of Common Market Studies 219; Willem Maas, 'EU Citizenship in Retrospect and Prospect' in Engin F Isin and Peter Nyers (eds), Routledge Handbook of Global Citizenship Studies (Routledge 2014); Sergio Carrera, 'The Framing of the Roma as Abnormal Citizens' in Elspeth Guild, Cristina Gortázar Rotaeche and Dora Kostakopoulou (eds), The Reconceptualisation of European Citizenship (Bril/Nijhoff 2014). 
settled-status-type arrangements in the current 28 Member States is troublesome and raises questions for the future success of EU citizenship in the European project. Who - or what may save it, only time will show. 


\section{Bibliography}

Acosta Arcarazo D, The Long-Term Residence Status as a Subsidiary Form of EU Citizenship: An Analysis of Directive 2003/109 (Brill Nijhoff 2011)

Austin-Greenall G and Lipinska S, 'Brexit and Loss of EU Citizenship: Cases, Options, Perceptions' (ECAS 2017) <http://ecas.org/wp-content/uploads/2017/12/Brexit-and-Lossof-EU-Citizenship-1.pdf > accessed 6 May 2019

Barnard C and Fraser-Butlin S, 'Free Movement vs. Fair Movement: Brexit and Managed Migration' (2018) 55 Common Market Law Review 203

Baroness Kennedy of The Shaws, 'EU Settlement Scheme. Letter from the Chairman of EU Justice Sub-Committee to Home Secretary' (27 February 2019) $<$ https://www.parliament.uk/documents/lords-committees/eu-justicesubcommittee/CWM/HKtoSJ-SettledStatus-260219.pdf> accessed 9 August 2019

Belavusau U and Henrard K (eds), EU Anti-Discrimination Law beyond Gender (Hart Publishing 2018)

Benton M, Safe or Sorry? Prospects for Britons in the European Union after Brexit (Migration Policy Institute Europe 2017)

Birkinshaw P and Biondi A, Britain Alone! The Implications and Consequences of United Kingdom Exit from the EU (Wolters Kluwer 2016)

Boeles P and others, European Migration Law (2nd edn, Intersentia 2014)

'Brits Abroad: How Many People from the UK Live in Other EU Countries?' Full Fact (1 February 2018) <https://fullfact.org/europe/how-many-uk-citizens-live-other-eucountries/> accessed 17 March 2019

Brookes M, Spheres of Justice: A Defence of Pluralism and Equality (Basic Books 1983)

Cambien N, 'EU Citizenship and the Right to Care' in Dimitry Kochenov (ed), EU Citizenship and Federalism: The Role of Rights (Cambridge University Press 2017)

Carrera S, 'The Framing of the Roma as Abnormal Citizens' in Elspeth Guild, Cristina Gortázar Rotaeche and Dora Kostakopoulou (eds), The Reconceptualisation of European Citizenship (Bril/Nijhoff 2014)

Church C, 'What Is the Swiss Model of Co-Operation with the European Union?' The Conversation (6 May 2016) <http://theconversation.com/what-is-the-swiss-model-of-cooperation-with-the-european-union-58817> accessed 6 May 2019

Coutts S, 'Citizens of Elsewhere, Everywhere and . . . Nowhere? Rethinking Union Citizenship in Light of Brexit' (2018) 69 Northern Ireland Legal Quarterly 231

Dagilyte E and Greenfields M, 'United Kingdom Welfare Benefit Reforms in 2013-2014: Roma between the Pillory, the Precipice and the Slippery Slope' (2015) 37 Journal of Social Welfare and Family Law 476

Dagilyte E, Lazowski A and Stasinopoulos P, 'The Importance of Being Earnest: Spelling of Names, EU Citizenship and Fundamental Rights' (2015) 11 Croatian Yearbook of European Law and Policy <http://www.cyelp.com/index.php/cyelp/article/view/233> 
De Vries K, 'The Integration Exception: A New Limit to Social Rights of Third-Country Nationals in European Union Law?' in Daniel Thym (ed), Questioning EU Citizenship: Judges and the Limits of Free Movement and Solidarity in the EU (Hart Publishing 2017)

Delpero C, 'Brexit: Germany to Guarantee Social Security Rights in No Deal Preparations' Europe Street News (16 December 2018) < https://europestreet.news/brexit-germany-toguarantee-social-security-rights-in-no-deal-preparations/> accessed 18 March 2019

--, 'UK Agrees with Switzerland, Norway, Iceland to Protect Citizens' Rights Regardless of Brexit Deal' Europe Street News (10 February 2019) <https://europestreet.news/ukswitzerland-agree-post-brexit-residents-rights-regardless-of-eu-deal/> accessed 9 February 2019

- - 'Residence, Citizenship, Social Benefits: What Changes for British Residents in the EU Part 2' Europe Street News (12 February 2019) < https://europestreet.news/residencecitizenship-social-benefits-what-changes-for-british-residents-in-the-eu-part-2/> accessed 17 March 2019

Donegan T and Teo E, 'Brexit: Free Movement of Persons' (2016) 31 Journal of International Banking Law and Regulation 565

Džankić J, 'Investment-Based Citizenship and Residence Programmes in the EU' (2015) EUI Working Paper RSCAS 2015/o8

-—, 'Immigrant Investor Programmes in the European Union (EU)' (2018) 26 Journal of Contemporary European Studies 64

European Commission, 'Relations with the Principality of Andorra, the Principality of Monaco and the Republic of San Marino Options for Closer Integration with the EU (Communication)' (2013) COM/2012/0680 final/2

- -, 'Security Union: A European Travel Information and Authorisation System - Questions \& Answers' (2018) MEMO/18/4362

- -, 'UK Nationals' Residence Rights in the EU27' (2019)

$<$ https://ec.europa.eu/info/brexit/brexit-preparedness/citizens-rights_en> accessed 30 July 2019

- - ' 'Preparing for the Withdrawal of the United Kingdom from the European Union on 30 March 2019: Implementing the Commission's Contingency Action Plan' COM(2018) 890 final

- - 'State of Play of Preparations of Contingency Measures for the Withdrawal of the United Kingdom from the European Union' COM(2019) 276 final

Fabbrini F, 'The Political Side of EU Citizenship in the Context of EU Federalism' in Dimitry Kochenov (ed), EU Citizenship and Federalism: The Role of Rights (Cambridge University Press 2017)

Fahey E and Ahmed T, On Brexit: Law, Justices and Injustices (Edward Elgar Publishing 2019)

Ferrera M, 'The JCMS Annual Lecture: National Welfare States and European Integration: In Search of a "Virtuous Nesting" (2009) 47 Journal of Common Market Studies 219 
Garner O, 'After Brexit: Protecting European Citizens and Citizenship from Fragmentation' [2016] EUI Working Paper LAW 2016/22

--, 'The European Citizens Initiative on a European Free Movement Mechanism: A New Hope or a False Start for UK Nationals after Brexit?' (European Law Blog, 23 February 2017) < https://europeanlawblog.eu/2017/02/23/the-european-citizens-initiative-on-aeuropean-free-movement-mechanism-a-new-hope-or-a-false-start-for-uk-nationals-afterbrexit/> accessed 31 July 2019

Guarascio F, 'UPDATE 2-EU Grants Six-Month Reprieve to Swiss Exchanges, Wants New Treaty' Reuters (17 December 2018) <https://www.reuters.com/article/swiss-euidUSL8N1YM28W> accessed 6 May 2019

Guild E, Peers S and Kingham J, 'After a Hard BREXIT - British Citizens and Residence in the EU' (2017) 31 Immigration, Asylum and Nationality Law 121

Hailbronner K, EU Immigration and Asylum Law: Commentary on EU Regulations and Directives (Beck CH / Hart / Nomos 2010)

Henley J, 'Portugal Plans Special Lanes for Britons in Airports after Brexit' The Guardian (17 January 2019) <https://www.theguardian.com/world/2019/jan/17/portugal-plans-speciallanes-for-britons-in-its-airports-after-brexit> accessed 17 March 2019

HM Government, ‘The UK’s Future Skills-Based Immigration System’ (2018)

Home Office, 'EU Settlement Scheme: Written Statement - HCWS1387'

--, 'EU Settlement Scheme: Derivative Right to Reside (Chen and Ibrahim/Teixeira Cases). Guidance for Caseworkers. Version 1.0'

-—, 'EU Settlement Scheme Statistics, June 2019’ (2019)

--, 'EU Settlement Scheme: Applicant Information' (GOV.UK)

$<$ https://www.gov.uk/government/collections/eu-settlement-scheme-applicantinformation> accessed 6 August 2019

Home Office and UK Visas and Immigration, 'Government Outlines No Deal Arrangements for EU Citizens' (28 January 2019) < https://www.gov.uk/government/news/governmentoutlines-no-deal-arrangements-for-eu-citizens $>$ accessed 28 August 2019

House of Commons Home Affairs Committee, 'EU Settlement Scheme: Government Response to the Committee's Fifteenth Report of Session 2017-19' (2019) HC 2592

House of Lords European Union Committee, 'Brexit: Acquired Rights' (2016) HL Paper 82

Huber J, 'EU Citizens in Post-Brexit UK: The Case for Automatic Naturalisation' (2019) o Journal of European Integration 1

Iglesias Sánchez S, 'The Constitutional Status of Foreigners and European Union Citizens: Loopholes and Interactions in the Scope of Application of Fundamental Rights' in Daniel Thym (ed), Questioning EU Citizenship: Judges and the Limits of Free Movement and Solidarity in the EU (Hart Publishing 2017)

Kochenov D (ed), EU Citizenship and Federalism: The Role of Rights (Cambridge University Press 2017) 
--, 'EU Citizenship and Withdrawals from the Union: How Inevitable Is the Radical Downgrading of Rights?' in Carlos Closa (ed), Secession from a Member State and Withdrawal from the European Union: Troubled Membership (Cambridge University Press 2017)

--, 'Investor Citizenship and Residence: the EU Commission's Incompetent Case for Blood and Soil' (Verfassungsblog, 23 January 2019) <https://verfassungsblog.de/investorcitizenship-and-residence-the-eu-commissions-incompetent-case-for-blood-and-soil/> accessed 5 August 2019

Kochenov D and Agarin T, 'Expecting Too Much: European Union's Minority Protection Hide-and-Seek' (2017) 1 Anti-Discrimination Law Review 7

Kochenov D and Brink M van den, 'Pretending There Is No Union: Non-Derivative QuasiCitzenship Rights of Third-Country Nationals in the EU', Rights of Third-Country Nationals under EU Association Agreements, vol 9 (Brill / Nijhoff 2015)

Kochenov D, De Búrca G and Williams A (eds), Europe’s Justice Deficit? (Hart Publishing 2015)

Kostakopoulou D, 'Towards a Theory of Constructive Citizenship in Europe' (1996) 4 Journal of Political Philosophy 337

--, Citizenship, Identity, and Immigration in the European Union: Between Past and Future (Manchester University Press 2001)

- - 'Scala Civium: Citizenship Templates Post-Brexit and the European Union's Duty to Protect EU Citizens' (2018) 56 Journal of Common Market Studies 854

Kuipers J-J, 'Cartesio and Grunkin-Paul: Mutual Recognition as a Vested Rights Theory Based on Party Autonomy in Private Law' (2009) 2 European Journal of Legal Studies 66

LRT, 'Lithuania's citizenship referendum: necessary but rushed vote' lrt.lt (8 May 2019) <https://www.lrt.lt/naujienos/news-in-english/19/1056843/lithuania-s-citizenshipreferendum-necessary-but-rushed-vote> accessed 6 August 2019

Maas W, 'EU Citizenship in Retrospect and Prospect' in Engin F Isin and Peter Nyers (eds), Routledge Handbook of Global Citizenship Studies (Routledge 2014)

Macdonald M, 'EU Settlement Scheme' (2019) House of Commons Library Briefing Paper 8584

McCarthy H, 'The End of the Retirement Dream? British Pensioners in the European Union after Brexit' (2018) 10 MPI Europe Brief 1

McKinney CJ, 'How New Immigration Regulations Will Make It Easier to Deport EU Citizens after Brexit' Free Movement (13 March 2019) < https://www.freemovement.org.uk/hownew-immigration-regulations-will-make-it-easier-to-deport-eu-citizens-after-brexit/> accessed 17 March 2019

Misicka S, 'What Is This EU Framework Deal?’ SWI swissinfo.ch (1 April 2019) $<$ https://www.swissinfo.ch/eng/politics/swiss-eu-relations_what-is-this-eu-frameworkdeal-/44865230> accessed 6 May 2019 
Montaldo S, 'Freedom of Movement, Social Integration and Naturalization: Testing Reverse Discrimination in the Recent Case Law of the Court of Justice' (2018) 3 European Papers 1481

Morano-Foadi S and Vries K de, 'The Equality Clauses in the EU Directives on Nondiscrimination and Migration/Asylum' in Sonia Morano-Foadi and Micaela Malena (eds), Integration for Third-Country Nationals in the European Union. The Equality Challenge (Edward Elgar 2012)

Newson N, 'EEA Nationals (Indefinite Leave to Remain) Bill [HL] HL Bill 38 of 2017-19. House of Lords Library Briefing' (House of Lords Library 2019) Lords Library notes LLN2019-0092

O'Brien C, Unity in Adversity: EU Citizenship, Social Justice and the Cautionary Tale of the UK (Hart 2017)

Office for National Statistics, 'Migration Statistics Quarterly Report: February 2019' (Office for National Statistics)

<https://www.ons.gov.uk/peoplepopulationandcommunity/populationandmigration/intern ationalmigration/bulletins/migrationstatisticsquarterlyreport/february2019> accessed 17 March 2019

Peers S, 'UK Citizens as Non-EU Citizens in the EU after Brexit: Applying the EU Directive on Non-EU Long-Term Residents' (EU Law Analysis, 27 December 2018) $<$ http://eulawanalysis.blogspot.com/2018/12/uk-citizens-as-non-eu-citizens-in-eu.html> accessed 5 August 2019

Reynolds S, '(De)Constructing the Road to Brexit: Paving the Way to Further Limitations on Free Movement and Equal Treatment?' in Daniel Thym (ed), Questioning EU Citizenship: Judges and the Limits of Free Movement and Solidarity in the EU (Hart Publishing 2017)

Rolfe H, 'Challenges for Immigration Policy in Post-Brexit Britain: Introduction' (2019) 248 National Institute Economic Review R1

Schaart E, 'Citizens' Rights for Brits in the EU If There's No Brexit Deal' Politico (31 January 2019) <https://www.politico.eu/article/citizens-rights-for-brits-in-the-eu-if-theres-nobrexit-deal/> accessed 17 March 2019

Schiek D, 'On the Never-Ending Road to Brexit: Perspectives for the European Union Introducing This Special Issue' (2018) 69 Northern Ireland Legal Quarterly 221

Schrauwen A, '(Not) Losing out from Brexit' (2017) 1 Europe and the World 1

Scicluna C, 'Malta to Offer Britons Renewable 10-Year Residency Permits' Reuters (23 January 2019) <https://www.reuters.com/article/us-britain-eu-malta-idUSKCN1PH1ON> accessed 17 March 2019

Shaw J, 'Citizenship and Free Movement in a Changing EU: Navigating an Archipelago of Contradictions' in Benjamin Martill and Uta Staiger (eds), Brexit and Beyond: Rethinking the Futures of Europe (UCL Press 2018)

Spaventa E, 'Seeing the Woods despite the Trees? On the Scope of Union Citizenship and Its Constitutional Effects' (2008) 45 Common Market Law Review 13 
Strumia F, 'European Citizenship and Transnational Rights: Chronicles of a Troubled Narrative' in Daniel Thym (ed), Questioning EU Citizenship: Judges and the Limits of Free Movement and Solidarity in the EU (Hart Publishing 2017)

Sumption M and Kone Z, 'Unsettled Status? Which EU Citizens Are at Risk of Failing to Secure Their Rights after Brexit?' (COMPAS, University of Oxford 2018) Migration Observatory Report

the3Million, 'The UK EU Settlement Scheme (UKEUSS) - on the Ground' <https://static.wixstatic.com/ugd/od3854_54946819c6b445cd9675b7e14d5f77d3.pdf> accessed 7 August 2019

- - 'EEA Nationals (Indefinite Leave to Remain) Bill - Briefing for Lords Second Reading. EU Settlement Scheme: From a Constitutive to Declaratory System' (2019)

Tobler C, 'One of Many Challenges after "Brexit": The Institutional Framework of an Alternative Agreement - Lessons from Switzerland and Elsewhere?' (2016) 23 Maastricht Journal of European and Comparative Law 575

Trendall S, 'Home Office Holds Firm on Digital-Only Status for EU Settlement Scheme' PublicTechnology.net (25 July 2019)

<https://www.publictechnology.net/articles/news/home-office-holds-firm-digital-onlystatus-eu-settlement-scheme> accessed 6 August 2019

Tryfonidou A, The Impact of Union Citizenship on the EU's Market Freedoms (Hart Publishing 2016)

Tryfonidou A, 'Citizenship-for-Sale Schemes and EU Law: Can Third-Country Nationals Buy Their Way into Becoming Subjects of EU Law?' in Samo Bardutzky and Elaine Fahey (eds), Framing the Subjects and Objects of Contemporary EU Law (Edward Elgar Publishing 2017)

UK Home Office, 'Final EU Settlement Scheme - Private Beta Testing Phase 1 Report' (2018) $<$ https://www.gov.uk/government/publications/eu-settlement-scheme-public-beta-testingphase-report/eu-settlement-scheme-public-beta-testing-phase-report> accessed 5 August 2019

- -, 'EU Settlement Scheme - Private Beta Testing Phase 2 Report' (2019) $<$ https://www.gov.uk/government/publications/eu-settlement-scheme-public-beta-testingphase-report/eu-settlement-scheme-public-beta-testing-phase-report> accessed 5 August 2019

United Nations Global Migration Database, 'International Migrant Stock by Destination and Origin'

<http://www.un.org/en/development/desa/population/migration/data/estimates2/estimat es15.asp> accessed 16 March 2019

van den Brink M and Kochenov D, 'Against Associate EU Citizenship' [2019] JCMS: Journal of Common Market Studies <https://doi.org/10.1111/jcms.12898>

Vargas-Silva C and Fernández-Reino M, 'EU Migration to and from the UK' (2018) $<$ https://migrationobservatory.ox.ac.uk/resources/briefings/eu-migration-to-and-from-theuk/> accessed 18 March 2019

Verschueren H, 'Scenarios for Brexit and Social Security' (2017) 24 Maastricht Journal of European and Comparative Law 367 
Warwick B and Murray C, 'What Brexit Means for Future of the Common Travel Area between Ireland and the UK' The Conversation (26 February 2019)

<http://theconversation.com/what-brexit-means-for-future-of-the-common-travel-areabetween-ireland-and-the-uk-112312> accessed 6 May 2019

Wesemann A, 'European Union Citizens in Post EU UK' in Karl August Sachsen Gessaphe, Nils Szuka and Juan J Garcia Blesa (eds), Legal Implications of Brexit (Fern Universität in Hagen 2018)

Wiesbrock A, Legal Migration to the European Union (Martinus Nijhoff 2010)

Yong A, The Rise and Decline of Fundamental Rights in EU Citizenship (Hart Publishing 2019)

115/78 Knoors [1979] ECLI:EU:C:1979:31

C-34/og Ruiz Zambrano [2011] ECLI:EU:C:2011:124

C-6o/oo Carpenter [2002] ECLI:EU:C:2002:434

C-67/14 Alimanovic [2015] ECLI:EU:C:2015:597

C-82/16 KA and Others [2018] EU:C:2018:308

C-132/93 Steen [1994] ECLI:EU:C:1994:254

C-133/15 Chavez-Vilchez [2017] ECLI:EU:C:2017:354

C-135/o8 Rottmann [2010] ECLI:EU:C:2010:104

C-14O/12 Brey [2013] ECLI:EU:C:2013:565

C-165/16 Lounes [2017] ECLI:EU:C:2017:862

C-192/99 Kaur [2001] ECLI:EU:C:2001:106

C-256/11 Dereci [2011] ECLI:EU:C:2011:734

C-299/14 García-Nieto [2016] EU:C:2016:114

C-308/14 Commission v UK [2016] ECLI:EU:C:2016:436

C-333/13 Dano [2014] ECLI:EU:C:2014:2358

C-369/9o Micheletti [1992] ECLI:EU:C:1992:295

C-376/o2 Stichting ‘Goed Wonen’ [2005] ECLI:EU:C:2005:251

C-434/og McCarthy [2011] ECLI:EU:C:2011:277

$C-456 / 12$ O\&B [2014] ECLI:EU:C:2014:135

$C-457 / 12 S \& G$ [2014] ECLI:EU:C:2014:136

C-541/15 Freitag [2017] ECLI:EU:C:2017:432 
Joined cases 42 and 49/59 SNUPAT [1961] ECLI:EU:C:1961:5

Joined Cases C-7/56 and C-3/57 to C-7/57 Algera and Others [1957] ECLI:EU:C:1957:7

Joined Cases C-64/96 and C-65/o6 Uecker and Jacquet [1997] ECLI:EU:C:1997:285

Agreement on the withdrawal of the United Kingdom of Great Britain and Northern Ireland from the European Union and the European Atomic Energy Community [2019] XT 21028/19

Decision of the EEA Joint Committee No 158/2007 of 7 December 2007 amending Annex V (Free movement of workers) and Annex VIII (Right of establishment) to the EEA Agreement [2008] OJ L124/20

Directive (EC) 2003/86 on the right to family reunification [2003] OJ L 251/12

Directive (EC) 2003/109 concerning the status of third-country nationals who are long-term residents [2003] OJ L16/44

Directive (EC) 2004/38 on the right of citizens of the Union and their family members to move and reside freely within the territory of the Member States [2004] OJ L158/77

Directive (EC) 2009/50 on the conditions of entry and residence of third-country nationals for the purposes of highly qualified employment [2009] L155/17

Directive (EU) 2014/36 on the conditions of entry and stay of third-country nationals for the purpose of employment as seasonal workers [2014] L 94/375

Directive (EU) 2014/66 on the conditions of entry and residence of third-country nationals in the framework of an intra-corporate transfer [2014] L157/1

Directive (EU) 2016/801 on the conditions of entry and residence of third-country nationals for the purposes of research, studies, training, voluntary service, pupil exchange schemes or educational projects and au pairing [2016] L 132/21

Political Declaration setting out the framework for the future relationship between the European Union and the United Kingdom [2018] XT 21095/18

Regulation 492/2011 on freedom of movement for workers within the Union [2011] OJ L141/1

Regulation 2018/1806 listing the third countries whose nationals must be in possession of visas when crossing the external borders and those whose nationals are exempt from that requirement [2018] L 303/39

Regulation 2019/592 amending Regulation 2018/1806 listing the third countries whose nationals must be in possession of visas when crossing the external borders and those whose nationals are exempt from that requirement, as regards the withdrawal of the United Kingdom from the Union [2019] OJ L103/1

Regulation (EU) 2016/399 of the European Parliament and of the Council of 9 March 2016 on a Union Code on the rules governing the movement of persons across borders (Schengen Borders Code) [2016] OJ L77/1 